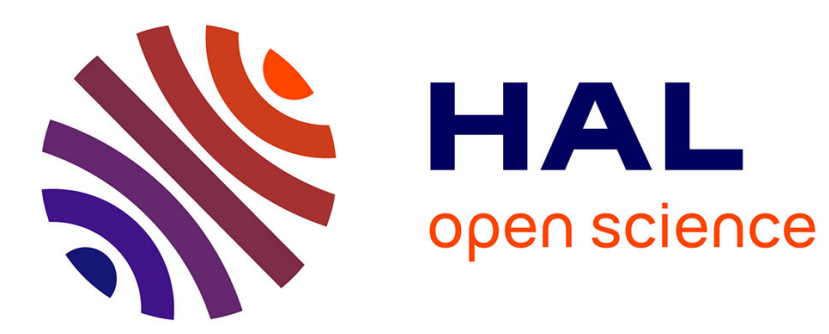

\title{
Neutron diffraction study in magnetic field of antiferromagnetic garnet $\mathrm{Ca} 3 \mathrm{Mn} 2 \mathrm{Ge} 3 \mathrm{O} 12$ \\ R. Plumier, M. Sougi
}

\section{To cite this version:}

R. Plumier, M. Sougi. Neutron diffraction study in magnetic field of antiferromagnetic garnet Ca3Mn2Ge3O12. Journal de Physique Lettres, 1979, 40 (10), pp.213-214. 10.1051/jphyslet:019790040010021300 . jpa-00231609

\section{HAL Id: jpa-00231609 https://hal.science/jpa-00231609}

Submitted on 1 Jan 1979

HAL is a multi-disciplinary open access archive for the deposit and dissemination of scientific research documents, whether they are published or not. The documents may come from teaching and research institutions in France or abroad, or from public or private research centers.
L'archive ouverte pluridisciplinaire HAL, est destinée au dépôt et à la diffusion de documents scientifiques de niveau recherche, publiés ou non, émanant des établissements d'enseignement et de recherche français ou étrangers, des laboratoires publics ou privés. 


\title{
LE JOURNAL DE PHYSIQUE-LETTRES
}

\section{Classification}

Physics Abstracts

75.25

\section{Neutron diffraction study in magnetic field of antiferromagnetic garnet $\mathrm{Ca}_{3} \mathrm{Mn}_{2} \mathrm{Ge}_{3} \mathrm{O}_{12}$}

\author{
R. Plumier and M. Sougi \\ DPh-G/PSRM, CEN Saclay, B.P. No 2, 91190 Gif sur Yvette, France
}

(Reçu le 24 janvier 1979, accepté le 30 mars 1979)

\begin{abstract}
Résumé. - Des expériences de diffraction des neutrons sous champ magnétique viennent d'être effectuées sur le grenat antiferromagnétique $\mathrm{Ca}_{3} \mathrm{Mn}_{2} \mathrm{Ge}_{3} \mathrm{O}_{12}$ de part et d'autre de $T_{\mathrm{N}}$. Elles mettent en évidence à la fois l'existence sous champ magnétique d'une phase métamagnétique à $T<T_{\mathrm{N}}$ ainsi que celle d'un ordre antiferromagnétique induit lorsque le champ magnétique est appliqué le long de [110].
\end{abstract}

\begin{abstract}
Neutron diffraction studies of antiferromagnetic garnet $\mathrm{Ca}_{3} \mathrm{Mn}_{2} \mathrm{Ge}_{3} \mathrm{O}_{12}$ in magnetic fields have been made above and below $T_{\mathrm{N}}$. They show the existence of a metamagnetic phase at $T<T_{\mathrm{N}}$ in finite magnetic fields and of an induced antiferromagnetic ordering at $T>T_{\mathrm{N}}$ when the magnetic field is applied along [110].
\end{abstract}

Recently, neutron diffraction experiments have been performed on powdered antiferromagnetic garnet $\mathrm{Ca}_{3} \mathrm{Mn}_{2} \mathrm{Ge}_{3} \mathrm{O}_{12}$ [1], [2], [3] (coined as $\mathrm{MnGeG}$ in [4]), at various temperatures, and as a function of magnetic field.

Figure 1 shows the temperature dependence of the (110), (310) and (211) reflections, the two first only being magnetic. The Néel temperature $T_{\mathrm{N}}=13.85 \mathrm{~K}$ obtained from specific heat measurements [2] is thus confirmed. At $4.2 \mathrm{~K}$, in the presence of a magnetic field aligned along the scattering vector $(H / / k)$, we observe at a threshold field of about $27 \mathrm{kOe}$ an increase in the (110) magnetic reflection (Fig. 2).

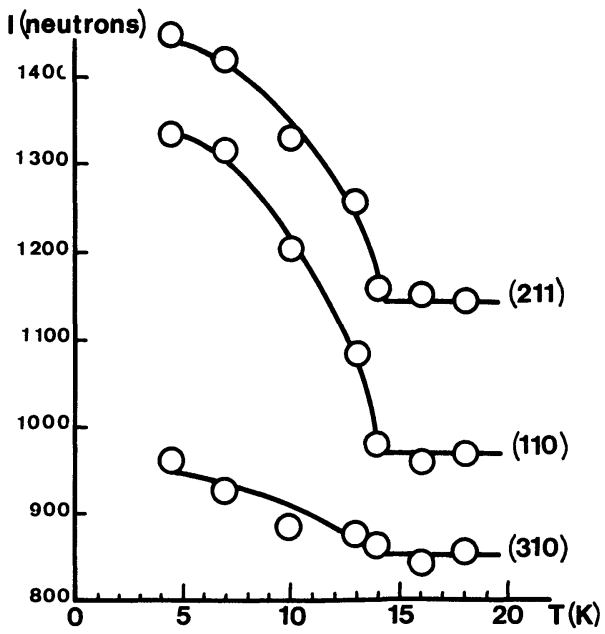

Fig. 1. - Temperature dependence of some magnetic reflections.

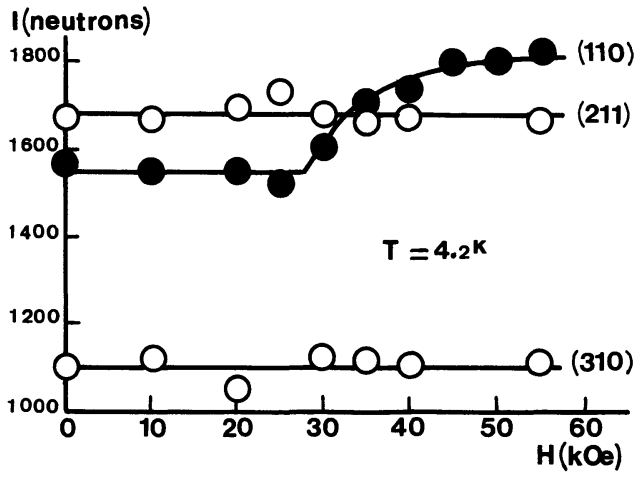

Fig. 2. - Evolution of some magnetic reflections in magnetic fields at $4.2 \mathrm{~K}$.

No intensity change may be detected in the other reflections at the same temperature and in magnetic fields up to $55 \mathrm{kOe}$ (Fig. 2).

At $4.2 \mathrm{~K}<T<T_{\mathrm{N}}$, the magnetic reflections (110), (211) and (310) have been followed in magnetic fields of up to $15 \mathrm{kOe}$ in the $(H / / k)$ situation. Except for an increase in the (110) reflection occurring at a critical field $H_{\mathrm{c}}(T)$ decreasing with temperature (Fig. 3), no modification of the other reflections is noticed. It is quite remarkable that the threshold magnetic field at which a jump is observed in the magnetization curves [1] has the same temperature dependence.

Again applying the magnetic field along the scattering vector at $T>T_{\mathrm{N}}$, we observe (Fig. 3), that the (110) 


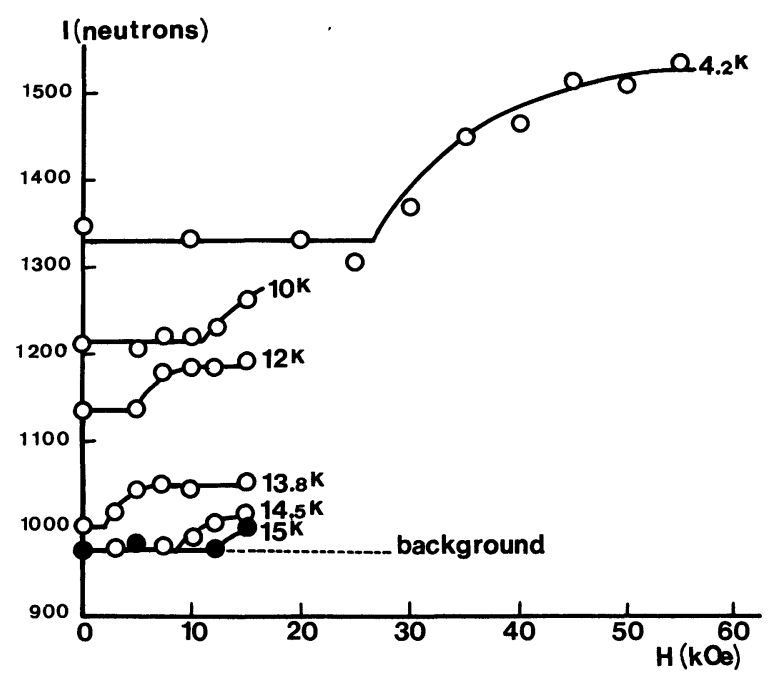

Fig. 3. - Temperature dependence of the threshold field for (110) intensity increase.

magnetic reflection reappears at a threshold field which is now an increasing function of temperature. No change is observed in the other reflections in that range of temperature. With a laboratory field not exceeding $15 \mathrm{kOe}$, the appearance of the (110) reflection has been followed up to $15.2 \mathrm{~K}$. Careful search indicates that there is no change in the line width of this reflection on both sides of $T_{\mathrm{N}}$ (Fig. 4).

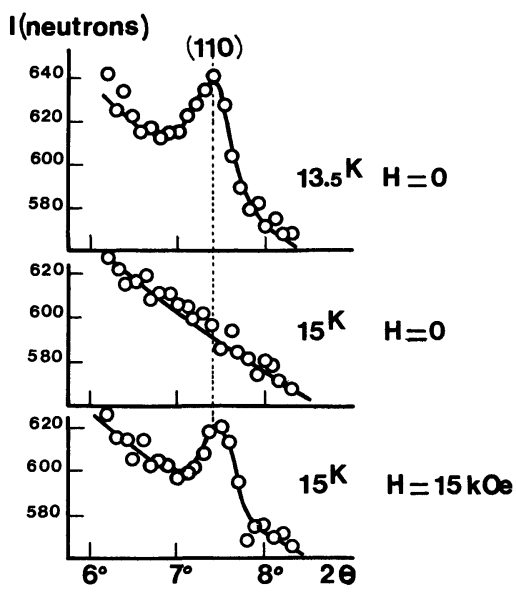

Fig. 4. - Magnetic (110) reflection on both sides of $T_{\mathrm{N}}$.

These neutron diffraction observations give weight to the expected phase diagram (Fig. 5) previously obtained [2] from specific heat and magnetization measurements and which indicates that even at $T>T_{\mathrm{N}}$ and at finite magnetic fields, a metamagnetic

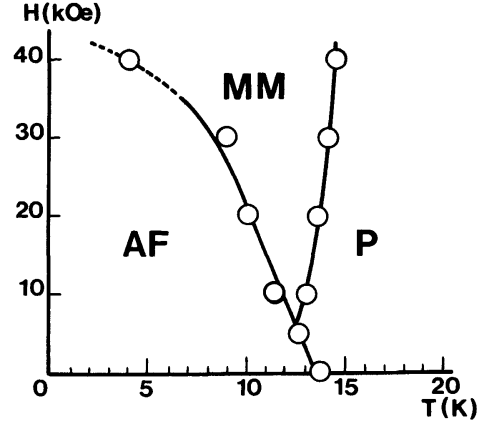

Fig. 5. - Phase diagram of $\mathrm{Ca}_{3} \mathrm{Mn}_{2} \mathrm{Ge}_{3} \mathrm{O}_{12}$ from Belov et al. [2].

structure becomes more stable than the magnetic structure observed in zero field.

In one of the experiments performed at $4.2 \mathrm{~K}$ under magnetic fields, the crystallites were left free to rotate. A further increase in the (110) magnetic reflection is observed, together with an increase of the nuclear reflection (220), indicating that in the metamagnetic phase $\mathrm{Ca}_{3} \mathrm{Mn}_{2} \mathrm{Ge}_{3} \mathrm{O}_{12}$ is a weak ferromagnet. No modification may be detected under such circumstances either of the other magnetic or of the nuclear reflections (Fig. 6).

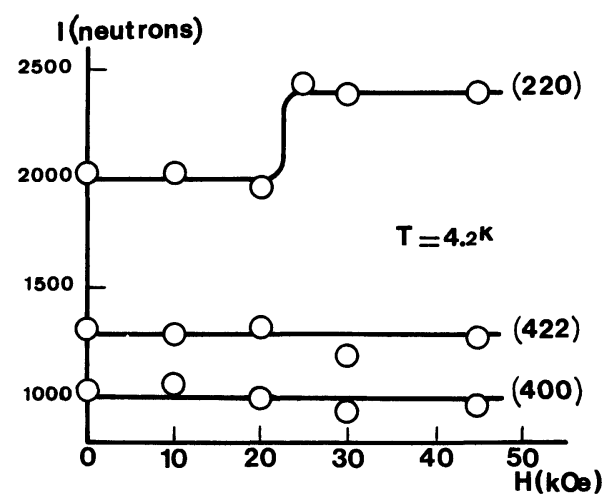

Fig. 6. - Nuclear reflections in magnetic field when free rotation of the crystallites is allowed.

At magnetic field values higher than the threshold field, the [110] direction may thus be regarded as an easy direction of magnetization. The particular part played by this direction has recently been confirmed by magnetization curves obtained with a single crystal of $\mathrm{Ca}_{3} \mathrm{Mn}_{2} \mathrm{Ge}_{3} \mathrm{O}_{12}$ [5].

Similar neutron diffraction experiments leading to finite magnetic intensities at $T>T_{\mathrm{N}}$ have recently been reported on the antiferromagnetic compound [6], $\mathrm{Cu}(\mathrm{HCOO})_{2} \cdot 4 \mathrm{D}_{2} \mathrm{O}$.

\section{References}

[1] Belov, K. P., Mill, B. V., Ronninger, G., SoKolov, V. I., HIEN, T. D., Sov. Phys. Solid State 12 (1970) 1393.

[2] Belov, K. P., Valyanskaya, T. V., Mamsurova, L. G., SokoLOV, V. I., Sov. Phys. JETP 38 (1974) 561.

[3] Plumier, R., Solid State Commun. 9 (1971) 1723.
[4] Belov, K. P. and Sokolov, V. I., Sov. Phys. Usp. 20 (1977) 149.

[5] Estève, D., Plumier, R., Feldman, P., Le Gall, H., to be published.

[6] Ajiro, Y., Endoh, Y., Terata, N., Matsuura, M., J. Phys. Soc. Japan. 45 (1978) 695. 